\title{
PELATIHAN PENGOLAHAN SAMPAH PLASTIK KRESEK SEBAGAI UPAYA PEMBERDAYAAN BURUH WANITA PENGANGKUT PASIR DI DESA MARONG JAMAQ KECAMATAN SELAPARANG MATARAM NUSA TENGGARA BARAT
}

\author{
Sri Puji Astuti ${ }^{*}$, Rina Kurnianingsih, Mursal Ghazali, Eka Sunarwidhi, dan Sunarpi \\ Fakultas MIPA, Universitas Mataram \\ Jl. Majapahit No. 62 Mataram. \\ ${ }^{*}$ Korespondensi: spastuti@unram.ac.id
}

Diterima 29 September 2018 / Disetujui 18 November 2018

\begin{abstract}
ABSTRAK
Kegiatan pengabdian pada masyarakat dengan khalayak buruh wanita pengangkut pasir di Desa Marong Jamaq Kelurahan Karang baru Kecamatan Selaparang, Kota Mataram, telah selesai dilaksanakan. Tujuan dari kegiatan ini adalah menumbuhkan dan mengasah keterampilan membuat produk dekoratif berbahan dasar sampah plastik kresek, memotivasi warga untuk mengembangkan kreativitas dan membuat usaha mandiri berbasis keterampilan mengolah sampah plastik kresek. Kegiatan ini dilakukan dengan pendekatan Focus Group Discussion, yang mencakup pelatihan, pembinaan dan evaluasi untuk memantau keberhasilan kegiatan menggunakan metode observasi. Materi yang disampaikan meliputi bahaya sampah plastik kresek bagi kesehatan dan lingkungan, upaya penanganan sampah plastik kresek skala rumah tangga, melatih pembiasaan dalam menciptakan lingkungan bersih, alternatif pemanfaatan sampah plastik kresek, aneka olahan sampah plastik kresek menjadi bahan dekoratif. Kesimpulan yang diperoleh dari kegiatan ini, sebanyak $100 \%$ peserta memahami materi yang disampaikan, sebanyak $85 \%$ peserta memahami cara pembuatan bahan dekoratif dari sampah plastik kresek, sebanyak $95 \%$ peserta termotivasi untuk menerapkan dan mengembangkan aneka model produk dekoratif, dan sebanyak $90 \%$ peserta termotivasi untuk memasarkan produk dekoratif yang telah dibuat.
\end{abstract}

Kata kunci: sampah plastik kresek, produk dekoratif, Desa Marong Jamaq

\section{PENDAHULUAN}

Salah satu tolok ukur kualitas hidup masyarakat adalah kualitas kebersihan lingkungannya (Wibowo, 2009). Usaha peningkatan kualitas kebersihan lingkungan telah diupayakan oleh pemerintah kota dan daerah di Indonesia. Salah satunya pada aspek pengelolaan sampah. Indonesia menjadi penyumbang sampah plastik terbesar kedua di dunia (Aziz, 2018), penghasil sampah terbesar adalah dikawasan pemukiman. Permasalahan sampah menjadi agenda utama permasalahan yang dihadapi hampir 
diseluruh daerah dan perkotaan di Indonesia. Upaya pengelolaan ini akan berhasil bila didukung oleh kemauan dan usaha nyata dari pemerintah kota dan daerah beserta masyarakat.

Banyak polusi muncul akibat pembuangan dan penumpukan sampah di tanah, sungai dan pembakaran sampah plastik. Permasalahan sampah di kota Mataram masih menjadi bahan diskusi untuk mencari solusi khususnya daerah sungai Jangkoq Kecamatan Selaparang. Sungai Jangkok memiliki panjang 47,1 kilometer yang melewati daerah perkotaan yang terindikasi mengalami pencemaran yang diakibatkan oleh aktivitas pembuangan limbah cair domestik, industri dan pertanian (Ruliantara, 2018).

Permasalahan utama sampah plastik kresek di daerah ini terletak pada daerah sungai yang kumuh, pemukiman penduduk yang sangat padat sampai ke daerah pinggiran sungai, banyaknya pertokoan dan jumlah tempat sampah yang terbatas membuat banyaknya masalah lain muncul.

Masyarakat di Desa Marong Jamaq terdiri atas buruh wanita pengangkut pasir dan pemecah batu, ibu rumah tangga yang kesehariannya beraktivitas di sekitar DAS Jangkok untuk mencari ikan menanam sayur. Masyarakat memanfaatkannya sebagai tempat mengambil pasir, batu dan pertanian.

Waktu luang buruh wanita pengangkut pasir dan ibu-ibu rumah tangga bila dimanfaatkan dengan melakukan aktifitas yang produktif tentu akan mampu meningkatkan perekonomian dan kesejahteraan keluarga di desa Marong Jamaq. Salah satu upaya yang dapat dilakukan untuk mengurangi tumpukan sampah plastik kresek melalui kegiatan pelatihan pengolahan sampah plastik kresek menjadi produk dekoratif dengan memberdayakan buruh wanita pengangkut pasir, pemecah batu dan ibu rumah tangga.

Harapan dengan adanya pelatihan pembuatan produk dekoratif dari sampah plastik kresek yang ramah lingkungan ini dapat menjadi salah satu alternatif pilihan untuk memulai wirausaha produksi maupun jasa dekoratif, sekaligus mengasah keterampilan dalam berinovasi membuat produk dekoratif lain berbahan dasar sampah plastik kresek.

\section{METODE KEGIATAN}

Pelatihan pembuatan produk dekoratif ini sangat mudah dilakukan dengan memanfaatkan bahan dasar yang jumlahnya melimpah dan menjadi sampah yakni plastik kresek. Tujuan dari kegiatan ini adalah memberikan bekal pengetahuan, keterampilan dan mengasah kreatifitas peserta dalam memanfaatkan plastik kresek menjadi barang bermanfaat dan bernilai ekonomi. salah satunya dengan membuat produk dekoratif. Ibu-ibu peserta dapat memulai usaha ini dengan membuat produk-produk dekoratif berupa rangkaian bunga plastik yang dapat dipasarkan maupun digunakan sendiri.

Selain itu ibu-ibu peserta dapat memulai usaha dibidang penyedia jasa dekoratif acara, baik kawinan, khitanan, kematian maupun hajatan lain. Bekal pengetahuan dan keterampilan yang diperoleh melalui kegiatan ini, diharapkan mampu menambah penghasilan ibu-ibu peserta selain sebagai buruh pengangkut pasir atau pemecah batu dan ibu rumah tangga, sehingga mampu meningkatkan taraf hidup keluarga.

Kegiatan ini melibatkan anggota Tim PPM yang berpengalaman dibidangnya 
dan memiliki latar belakang keilmuan yang relevan dengan materi yang disampaikan. Dukungan dari pihak Kepala Desa dan jajarannya dalam memberikan kesempatan warga untuk mengikuti kegiatan ini dari awal hingga akhir. Warga akan memperoleh manfaat berupa transfer ilmu, keterampilan dan pembinaan dari Tim PPM sebagai bekal memulai wirausaha mandiri maupun kelompok, sedangkan pihak desa memperoleh manfaat berupa berdayanya masyarakat di Desa Marong Jamaq dalam peningkatan taraf hidup masyarakat.

Kegiatan PPM ini menggunakan pendekatan metode Focus Group Discussion (FGD), materi-materi yang disampaikan mencakup pembekalan peserta mengenai bahaya sampah plastik kresek, upaya penanganan sampah plastik kresek pada skala rumah tangga, melatih kebiasaan dalam menciptakan lingkungan dan sanitasi bersih, memiliki gambaran alternatif pemanfaatan sampah plastik kresek.

Penerapan metode FDG cukup efektif, diharapkan materi yang disampaikan dapat diterima dengan baik. Selain itu, warga dapat membangun wirausaha baik pribadi maupun kelompok dengan menjual dan menyediakan jasa rangkai dan dekorasi.

khalayak sasaran adalah buruh wanita pengangkut pasir dan pemecah batu, serta ibu-ibu rumah tangga Desa Marong Jamaq. Langkah-langkah yang dilakukan dalam kegiatan ini meliputi: tim pengabdi dan kelompok ibu rumah tangga melakukan koordinasi terlebih dahulu untuk merancang metode dan jadwal kegiatan.

Tim pengabdi melakukan sosialisasi program dan koordinasi dengan Kepala Desa Marong Jamaq, pembelian bahan dan penyiapan alat-alat pembuatan produk dekoratif, uji coba pembuatan produk dekoratif, persiapan akhir dan pengedaran undangan, menjelaskan materi tentang bahaya sampah plastik kresek, menjelaskan materi tentang upaya penanganan sampah plastik kresek pada skala rumah tangga, menjelaskan tentang melatih pembiasaan dalam menciptakan lingkungan dan sanitasi bersih.

Menjelaskan tentang memiliki gambaran alternatif pemanfaatan sampah plastik kresek, mendemons-trasikan cara pembuatan produk dekoratif berbahan dasar sampah plastik kresek, melakukan evaluasi kegiatan.

\section{HASIL DAN PEMBAHASAN}

$\begin{array}{lcrr}\text { Kegiatan } & \text { PPM } & \text { dengan } & \text { judul } \\ \text { pemanfaatan sampah } & \text { plastik } & \text { dalam } \\ \text { pembuatan kerajinan } & \text { tangan } & \text { untuk } \\ \text { mengasah keterampilan buruh } & \text { wanita }\end{array}$
pengangkut pasir di desa Marong Jamaq Kota Mataram, telah dimulai sejak bulan Juli 2018. Kegiatan ini diawali dengan tahap sosialisasi dan koordinasi antar mitra, buruh wanita pengangkut pasir, buruh wanita pemecah batu, serta ibu rumah tangga. Peserta dibekali dengan materi oleh Tim pengabdian. Dari serangkaian kegiatan pengabdian ini, ditemukan beberapa kendala diantaranya, belum terbiasanya ibu-ibu memotong bahan-bahan dengan rapi dan terarah, masih terkendalanya dalam memunculkan kreativitas dalam merangkai baik model rangkaian maupun bentuk bunga yang dihasilkan.

Secara keseluruhan, kegiatan ini berjalan dengan lancar, peserta sangat antusias dalam mengikuti kegiatan dari awal hingga akhir (Gambar 1). Hal ini dibuktikan dengan peserta membuat 
kembali bunga kresek secara mandiri (Gambar 2).

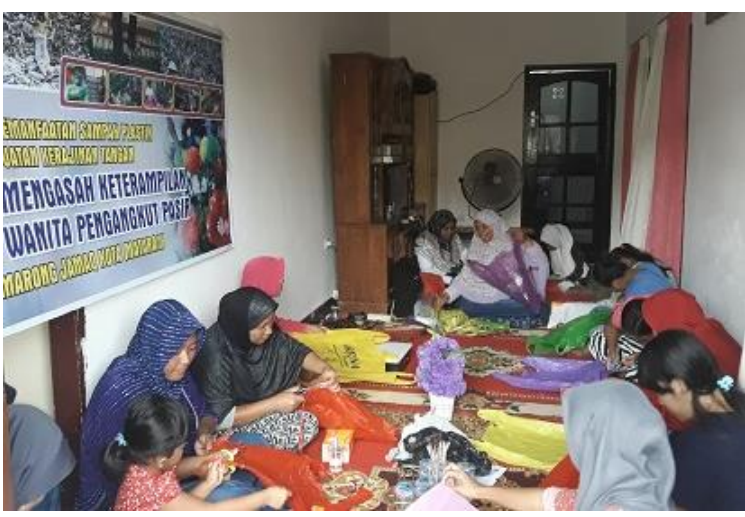

Gambar 1. Proses pelipatan plastik kresek

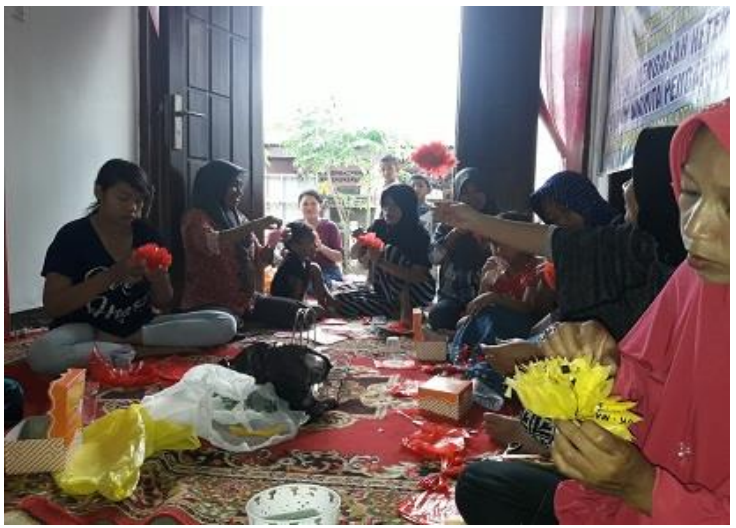

Gambar 2. Peserta membuat kembali bunga kresek secara mandiri

Hasil evaluasi terhadap kegiatan ini menunjukkan bahwa sebanyak $100 \%$ peserta memahami materi yang disampaikan, sebanyak $85 \%$ peserta memahami cara pembuatan bahan dekoratif dari sampah plastik kresek, sebanyak $95 \%$ peserta termotivasi untuk menerapkan dan mengembangkan aneka model produk dekoratif, dan sebanyak $90 \%$ peserta termotivasi untuk memasarkan produk dekoratif yang dibuat. Hasil evalusi ini dapat dilihat pada Gambar 3.

Hasil produk dekoratif yang dihasilkan memiliki keunggulan diantaranya berbahan dasar plastik sehingga dapat digunakan untuk dekorasi in door maupun out door, warnanya yang kilap sehingga menimbulkan kesan elegan dan menarik, bahan pendukung yang digunakan sangat sederhana dan mudah diperoleh, mudah dalam pembuatan dan bergantung pada kreativitas masingmasing. Sehingga dengan adanya kegiatan ini, masyarakat mendapat tambahan keterampilan dan wawasan mengenai pemanfaatan plastik kresek.

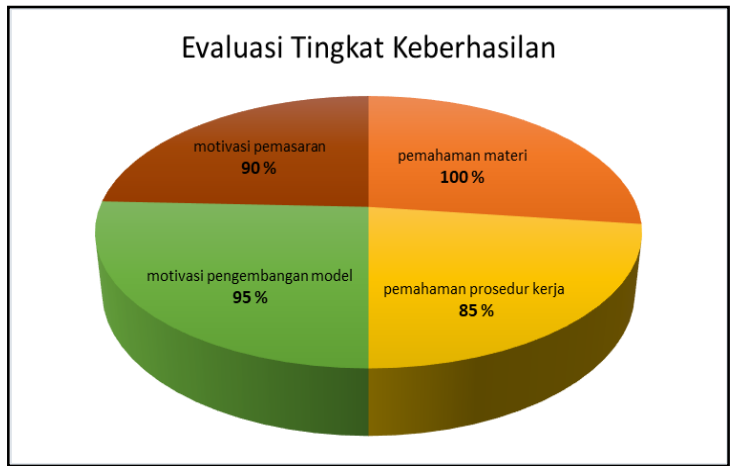

Gambar 3. Evaluasi tingkat keberhasilan kegiatan

Selain itu, keterampilan ini dapat dikembangkan oleh tiap peserta melalui pembinaan lanjutan. Ibu-ibu peserta dapat memanfaatkan keterampilan menjadi alternatif usaha dengan membuat produkproduk dekoratif berupa rangkaian bunga plastik yang dapat dipasarkan maupun digunakan sendiri, selain itu ibu-ibu peserta dapat memulai usaha dibidang penyedia jasa dekoratif acara, baik kawinan, khitanan, kematian maupun hajatan lain.

\section{KESIMPULAN DAN SARAN}

\section{Kesimpulan}

Kegiatan PPM pengolahan sampah plastik kresek yang dilakukan berjalan dengan baik, masyarakat memahami 
materi yang disampaikan. Dari keseluruhan rangkaian kegiatan, sekitar 90\% masyarakat sangat antusias untuk memasarkan produk dekoratif yang telah dibuat.

\section{Saran}

Perlu dilakukan pendampingan secara kontinu kepada mitra agar usahanya dapat berjalan secara berkesinambungan.

\section{Ucapan Terima Kasih}

Terselenggaranya kegiatan ini tidak lepas dari peran serta dan dukungan yang sudah diberikan oleh berbagai pihak, diantaranya LPPM Unram melalui pendanaan DIPA BLU anggaran 2018, Kepala desa beserta staf jajaran di kantor Desa Marong Jamaq, segenap warga desa Marong Jamaq.

\section{DAFTAR PUSTAKA}

Aziz, N., 2018. Indonesia sangkal penyumbang sampah plastik terbesar di kawasan. https://www.bbc.com/ indonesia/majalah-42833138. indonesia: BBC news, indonesia.

Ruliantara, A.D., 2018. Analisis Kualitas Air dan Strategi Pengendalian Pencemaran Terhadap Sungai Jangkok Di Kota Mataram, Nusa Tenggara Barat. Malang. Universitas Brawijaya.

Wibowo, I., 2009. Pola perilaku Kebersihan: Studi Psikologi Lingkungan Tentang Penanggulangan Sampah Perkotaan. MAKARA, Sosial Humaniora, 13 (1): 37-47. 